tissues also. No proteolytic enzyme predigestion of sections is required. This can sometimes affect the quality of the sections. However, a brief period of processing in a microwave oven is needed. This is a critical and essential step which has to be carried out in the precise manner described. The results obtained with 1D5 were more intense, but otherwise comparable with those obtained with ER-ICA antibody when used on paraffin wax sections.

Although the staining results were less intense than those obtained with frozen sections, paraffin wax sections have the obvious advantage of using routinely processed tissue and they provide sections of higher quality which are easier to interpret.

The semiquantitative scoring system used is simple and reproducible. Its results correlate well with the quantitative estimates obtained with DCC. The scores can provide an estimate of the level of ER in a given tumour and whether it is absent, low, moderate, high or very high which may be of value to oncologists.

This study was partly supported by a grant from Dako Ltd.

1 Scottish Cancer Trials Breast Group and ICRF Breast Unit, Guy's Hospital, London. Adjuvant ovarian ablation versus $\mathrm{CMF}$ chemotherapy in premenopausal women with pathological stage II breast carcinoma: the Scottish trial. Lancet 1993;341:1293-8.

2 Shintaku IP, Said JW. Detection of estrogen receptors with monoclonal antibodies in routinely processed formalin-fixed paraffin sections of breast carcinoma. Use of DNase pretreatment to enhance sensitivity of the reaction. Am 7 Clin Pathol 1987;87:161-7.

3 Elias JM, Heimann A, Cain T, Margiotta M, Gallery F, Gomes C. Estrogen receptor localization in paraffin sections by enzyme digestion, repeated applications of sections by enzyme digestion, repeated applications of
primary antibody, and imidazole. $₹$ Histotechnol 1990;13:

4 Soomro S, Shousha S, Sinnett HD. Oestrogen and progesterone receptors in screen-detected breast carcinoma: an immunohistological study using paraffin sections. Histopathology 1992;21:543-7.

\title{
Prevalence of Epstein-Barr virus in the cervix
}

\author{
Y Taylor, W T Melvin, H F Sewell, G Flannelly, F Walker
}

\begin{abstract}
Cervical smears from 327 women were examined using the polymerase chain reaction (PCR) targeted to a sequence in the Bam H1 W region of the Epstein-Barr virus (EBV) to determine the prevalence of the virus in the cervix. EBV was detected in 131 (40\%) of the 327 women. Of the 235 women with normal cytology, $98(42 \%)$ were positive. Of the 92 women with dyskariotic smears, 33 (36\%) were positive.
\end{abstract}

(F Clin Pathol 1994;47:92-93)

Department of Pathology, University of Aberdeen Medical School, Aberdeen, AB9 2ZD Y Taylor F Walker

Department of Molecular and Cell Biology

W T Melvin

Department of Obstetrics and Gynaecology G Flannelly

Department of Immunology, University of Nottingham H F Sewell Correspondence to: Professor F Walker cervix is another site where the virus is shed and can replicate, ${ }^{3}$ the role of EBV in cervical neoplasia requires elucidation. As an initial step it was decided to establish if EBV is

In almost all healthy EBV antibody positive people the major site from which the virus is shed is the oropharynx, and viral replication seems to be restricted to squamous epithelial commonly present in the cervix and whether there is any difference in its prevalence in cytologically normal and cytologically dyskariotic cervices.

\section{Methods}

The study population of 327 was drawn from the Grampian call/recall cervical screening programme. It consisted of 235 women (mean age 33.4, range 17-67 years) with normal cervical smears attending family planning and general practitioner clinics, and 92 women (mean age $31 \cdot 8$, range 18-62 years) with dyskariotic smears attending colposcopy clinics. Ninety of the latter group had confirmation of squamous epithelial abnormalities in biopsy specimens taken subsequent to the smears.

Cervical smears collected with a spatula were collected into phosphate buffered saline and stored at $-20^{\circ} \mathrm{C}$ until DNA extraction. All DNA samples were subjected to an amplification reaction directed to a portion of the $\beta$ globin gene to validate the quality of the extracted DNA. ${ }^{4}$

The polymerase chain reaction (PCR) was targeted to a sequence in the Bam H1 W region of the EBV genome. ${ }^{5}$ Reactions were carried out in $50 \mu \mathrm{l}$ volumes containing $50 \mathrm{mM} \mathrm{K} \mathrm{Cl}, 10 \mathrm{mM}$ TRIS- $\mathrm{HCl}$ (pH 8.3), $1 \mathrm{mM} \mathrm{Mg} \mathrm{Cl}, 0.01 \%$ gelatine, $200 \mu \mathrm{M}$ each dNTP (dATP, dGTP, dCTP and dTTP), 
1.0 $\mu \mathrm{M}$ each primer, 2.5 units Taq enzyme and $0 \cdot 1 \mu \mathrm{g}$ DNA. Reaction mixes were overlayed with mineral oil and amplifications performed in a Perkin Elmer thermal cycler. After an initial denaturation step of five minutes at $94^{\circ}, 30$ cycles were performed at $94^{\circ}$ for one minute and $59^{\circ}$ for 30 seconds (2nd stage only), with a final seven minute extension at $72^{\circ} \mathrm{C}$. PCR products were visualised under ultraviolet light on $\mathbf{1 . 5 \%}$ agarose gels containing ethidium bromide. The specificity of the reactions was confirmed by Southern blotting and, in some instances, by sequencing of cloned PCR products. Each sample was amplified in duplicate.

\section{Results}

Overall, 131 (40\%) of the 327 women had EBV in their cervical smears. Of the 235 with normal smears, 98 (42\%) were EBV positive. Of the 92 with dyskariotic smears, 33 (36\%) were EBV positive.

\section{Discussion}

These results show that the cervix frequently harbours EBV. The actual prevalence figures compare with five (18\%) EBV positive results, from 28 women, originally reported as of undetermined cytological status, ${ }^{3}$ and 12 (33\%) from 36 women with cervical epithelial abnormalities. ${ }^{6}$ The former study used less sensitive techniques of cell transformation and in situ hybridisation: the latter study, corresponding to our own dyskariotic group, used PCR.

The source of the EBV is not determinable from our study but there are three main possibilities. The virus could be shedding in its cell free infectious form; the scrape might contain lymphocytes and those with the EBV/C3d receptor could well harbour the virus; and cervical squamous epithelial cells can replicate EBV infection. None of these possibilities is exclusive.
There is a compelling body of evidence that cervical neoplasia, especially cervical intraepithelial neoplasia (CIN), is related to viral infection. The questions of which virus is, or which viruses are, involved remain unanswered, but EBV is unlikely to act alone because its prevalence in normal and abnormal cervices is similar. However, EBV is certainly a candidate in a multiviral hypothesis. In hairy cell leucoplakia of the tongue a lesion with a histological semblance to cervical dysplasia, there is sound evidence that both EBV and human papilloma virus (HPV) are implicated. ${ }^{7} \mathrm{HPV}$ of various types is very common in the cervix. Synergism between EBV and HPV is a possibility, perhaps by way of the former expressing the BCRF1 gene, ${ }^{8}$ which codes for an interleukin-10 (IL-10)-like molecule, ${ }^{9}$ which can modulate the immune reaction to both viruses. This merits further investigation.

This work was supported by Harris Birthright and Grampian Health Board.

1 Fingeroth JD, Weis JI, Tedder TF, Strominger JL, Biro PA, Fecron DT. Epstein-Barr virus receptor of human B lymphocytes is the C3d receptor CR2. Proc Natl Acad Sci USA 1984;81:4510-14.

2 Sixbey JW, Nedrud JG, Raab-Traub N, Hanes RA, Pagano JS. Epstein-Barr virus replication in oropharyngeal epithelial cells. N Engl f Med 1984;310:1225-30.

3 Sixbey JW, Lemon SM, Pagano JS. A second site for Epstein-Barr virus shedding: the uterine cervix. Lancet $1986 ; \mathrm{ii} ; 1122-4$.

4 Saiki RK, Scharf S, Faloona F, et al. Enzymatic amplification of $\beta$-globin genomic sequences and restriction site tion of $\beta$-globin genomic sequences and restriction site analysis for diagn

5 Jones MD, Griffin BE. Clustered repeat sequences in the genome of Epstein-Barr virus. Nucleic Acids Res 1983; 11:3919-37.

6 Bevan IS, Blomfield PI, Johnson MA, Woodman CBJ, Young LS. Oncogenic viruses and cervical cancer. Lancet 1989 ; i:907-8.

7 Greenspan JS, Greenspan D, Lennette ET, et al. Replication of Epstein-Barr virus within the epithelial cells of oral "hairy" leukoplakia, an AIDS-associated lesion. N Engl f Med 1985;313:1564-71.

8 Moore KW, Vieira P, Fiorentino DF, et al. Homology of cytokine synthesis inhibitory factor (IL-10) to the
Epstein-Barr virus gene BCRF1. Science 1990;248: Epstein-Bar $1230-4$.

9 Di-Hwei $\mathrm{H}$, Malefyt RdV, Fiorentino DF, et al. Expression of interleukin-10 activity by Epstein-Barr virus protein BCRF1. Science 1990;250:830-2. 